\title{
DEVELOPING MODEL OF VOCATIONAL SKILL LEARNING MANAGEMENT TO PREPARE MILD MENTALLY RETARDED CHILDREN IN ENTERING THE WORLD OF WORK
}

\author{
Rejokirono ${ }^{1 *}$, Sunardi ${ }^{2}$, Suparno ${ }^{3}$, Lantip Diat Prasojo ${ }^{3}$ \\ 1 Universitas Sarjanawiyata Tamansiswa \\ 2Universitas Negeri Surakarta \\ 3Universitas Negeri Yogyakarta \\ 1Jl. Batikan, Tahunan, Umbulharjo, Kota Yogyakarta, Daerah Istimewa Yogyakarta 55167 \\ 2Jl. Ir. Sutami No.36A, Jebres, Kota Surakarta, Jawa Tengah 57126 \\ 3Jl. Colombo No. 1, Depok, Sleman 55281, Yogyakarta, Indonesia \\ * Corresponding Author. Email: rejokironodr@gmail.com
}

\begin{abstract}
This study aims: (1) to map the practice of skill learning management in several special schools recently; (2) to gain information of things needed in developing the skill learning model (3) to create vocational skill learning management model to prepare mild mentally retarded children in entering the world of work; (4) and to find out information of the model effectiveness. The design of this research and development broadly comprises three phases: (1) the preliminary study covering the literature study, the arena study,(2) questionnaire distribution and need analysis through the FGD with 30 headmasters, 102 teachers and 33 parents from 33 special schools in Yogyakarta as the research subject; (3) the model development including the formulation of the model, validation of the model draft by 14 practitioners (headmaster and teacher) and 10 experts, and the revision of the model; and (4) the limited testing by 6 practitioners, the small group testing by 12 practitioners, the extended testing by 33 practitioners, and final model revision. Data analysis uses descriptive statistical analysis techniques and descriptive qualitative analysis. The results show that: 1) the practice of vocational skill learning management in special schools recently outlining following evidences (a) the skill material is not appropriate to the needs of DUDI (World of Business and Industry), (b) study group classification is based on the class grade, (c) thematic learning approach is in line with the skill themes, (d) the use of drilling methods, (e) learning evaluation is oriented on the result, (f) has not organized field practice (PKL) and job training yet, (g) schools have not established cooperation with parents and DUDI yet, and (h) the headmasters have not fully implemented the management function. 2) the needs of model development are (a) vocational skill material selection based on the need of DUDI; (b) study group classification based on the types of skill; (c) thematic learning approach based on the skill themes; (d) the use of drilling methods; (e) learning evaluation on the process and result; (f) organizing field practice and job training; (g) establishing cooperation with parents and DUDI; (h) the charismatic headmasters who have a lot of ideas are able to implement the function of management in vocational skill learning. 3) The resulting model are (a) vocational skill material selection based on the need of DUDI; (b) study group classification based on the types of skill; (c) thematic learning approach based on the skill themes; (d) the use of drilling methods; (e) learning evaluation on the process and result; (f) organizing field practice and job training; $(\mathrm{g})$ establishing cooperation with parents and DUDI; (h) the charismatic headmasters who have a lot of ideas are able to implement the function of management in vocational skill learning. 4) The result of model content testing in very good category and the result of model applicability testing in very good category.

Keywords: learning management, vocational skills, mild mentally retarded children ready to enter the world of work
\end{abstract}

Permalink/DOI: http://dx.doi.org/10.21831/amp.v6i2.17136 


\section{Introduction}

According to the data taken from Educational Primary Data (DAPODIK) in 2017 shows that the number of special need children studying at special school in Yogyakarta is about 5,023 . The number covers 12 special schools in Gunungkidul district with 729 children, 20 special schools in Bantul District with 1,531 children, 8 special schools in Kulon Progo District with 532 children, 29 special schools in Sleman District with 1,579 children, and 9 special schools in Yogyakarta with 652 children.

All students consist of Visual Impairment (A) $4.48 \%$ (222 children), Hearing Impaired Speech (B) 14.99\% (753 children), Mild Mentally Retarded (C) 66.80\% (3.355 children), Orthopedically Handicapped (D) $1.87 \%$ (94 children), Unsociable (E) $0.78 \%$ (155 children), dan Autis 8.84\% (444 children). The data shows that the number of mild mentally retarded children is the highest of all. Mild mentally retarded children have the lowest self-reliance level of other special need children. It can be interpreted that if there is no any concern to them, there will be more unemployed special need children. The problem cannot certainly be left alone, but it needs to find out the solution. This study is trying to give contribution to the improvement of the educational management for mild mentally retarded children by giving various applied vocational skills that help them work.the contribution will be about the implementation of management function covering planning, organizing, executing, and evaluating toward vocational skill learning.

Mild mentally retarded children or Intellectual Disabillity level Mild skill domain has several characteristics as stated by (American Psychiatric Association, 2013, p. 36), that they need assistance in complex daily activity. In their teenage and adult, the assistances include shopping daily meal, transportation, household and preparing/ serving dish. Vocational skill trained must be adjusted by the difficulty level and the needs of special need children and children carrier development.
According to Syamsi (2010, p. 90) the results of his research stated that the development of training for children with special needs to become new entrepreneurs with a flexible and practical entrepreneurship training, the affordable cost of implementation, the flexible implementation, the fast implementation process, can be implemented by anyone and everywhere reflecting a basic form of robust and future oriented entrepreneurship training.

According to Levinson \& Palmer (2005, pp. 11-15):

For most people, work is essential to a livelihood, a sense of worth and accomplishment, and overall life satisfaction. Unfortunately, a disproportionate number of students with disabilities or low academic performance do not go on to experience steady, satisfying, or gainful employment. Schools must give more focus, in both time and resources, to preparing noncollege track students for work or postschool training. A comprehensive transdisciplinary approach to both assessment and planning are essential elements of programs that successfully prepare students for postschool life.

According to (Rejokirono, 2015, pp. 87-104), the time allocation for skills learning that reaches $70 \%$ should be enlarged in the DUDI practice so they will not be awkward if they come to the real work. Field Practice is allocated at least one month in one semester while the technical things are submitted to teachers and employers. Some of the field practices are taken by weekly system and the other one is taken for twice a week in DUDI,

Shahid, Naheed, \& Javed (2012, p. 14) stated that the result showed that teachers actively perform to motivate and encourage the students thereby creating interest regarding vocational training among them. And students are getting equal opportunities of training as normal children. Teachers take a part actively in motivating and encouraging students. Furthermore, the study concluded that special students are very much satisfied with the vocational training programs and they are confident about 
getting employment opportunities in near future.

According to Steyn \& Vlachos (2011), teachers take part actively in motivating children with special need to follow the vocational training program. Vocational training program can improve children' confidence, but it should be maintained continuously to train children with special need in greater number.

Go further Steyn \& Vlachos (2011) explained deeply below.

Little information is available on future vocational preparation for intellectually disabled students in South African schools. Currently teachers adapt the National Curriculum Statement (NCS) to educate these students. The NCS was adapted to make the learning material suitable for intellectually disabled students. The programme was implemented and a mixed method research design facilitated a case study done in a school for intellectually disabled students. Findings revealed that a school vocational training programme can be managed successfully to the benefit of the parents, students and Department of Education.

Steyn \& Vlachos conclusion shows that it depends on the punctuality, hardworking, the ability of adapted communication, attitude to other, the use of tools and materials, output quality and the consistence of the achievement differs from good and worthy. Furthermore Steyn \& Vlachos stated:

...Vocational training should be fully integrated into the overall educational system within the school. The programme should be enforced legally and form part of the curriculum and be an addition to the school programme. Meanwhile teachers will have to take responsibility for their own professional development to facilitate vocational training classes.

Vocational Training Program should be integrated well in the whole of education system at school. The program must be conducted legally and be a part of the curriculum and not be an additional program at school. Student with poor ability will be better if he is encouraged with the repeated assignments. The ability including tasks fulfillment less than a week takes a longer time to complete it properly.

Furthermore, according to Abtahi, Naraghi, \& Shariatmadari (2010, pp. 517528)

Thus, helping the intellectually disabled students in Iran to acquire job empowerment skill, but the other two groups, the teachers and employers, believed it lacks enough competence and efficiency to do so. The results have been illustrated in a model developed by the researcher has been brought at the end of the article.

The main objective of this study is empowering the job role in the vocational secondary school curriculum system for male mild mentally retarded students who can be trained in Iran. For the outcome of this study focuses on the influence of each curriculum element (objectives, content, time, and evaluation procedures), on each work skills element (general and social skills, self-management, economic adequacy, and professional rehabilitation). The result is illustrated in a model developed by the researcher, as follows: The purpose of educating the trainable mentally-retarded students is to prepare them for life and help them to learn skills to lead an independent or the least dependent life. The objectives of the curriculum are to train them to find a job and to keep their future occupation.

The result of Mumpuniarti's (2006, p. 16) research, development of vocational ability of mild mentally retarded student needed a management or development management to get effective and efficient effort. This form of management needs to be undertaken by special schools of mild mentally retarded student by means of cooperation with parents, community service providers, and other professionals, when planning the vocational type to be fostered, resources that can be used, phasing in coaching, addressed with the vocational type, the pattern of implementation in coaching, and evaluation of success.

According to (Supartini, Suharmini, \& Purwandari, 2010), the findings of the study showed: (1) development of life skill education substance model for mild mentally 
retarded children was as follows (a) studying the theories of life skills for mild mentally retarded children, (b) studying GBPP Bina Diri for mild mentally retarded children (d) identifying parents 'expectations, (e) identifying students' abilities and potentials, (2) Have teacher the handbooks validated by media experts, and materials reviewers from academic staffs who are educating mild mentally retarded children, headmasters and teachers of SLB, (3) The teacher handbook has been socialized to several SLBs, and several books are placed in the Yogyakarta State University Library.

Nanda, Silvia, \& Kasiyati (2014, p. 562) stated that supervising teachers have a big role in training their students skills to be a team that attracts the business community to have cooperation in terms of livestock development, and one of them is the business world in marketing of quail eggs.

Anwaruhamka (2010, p. 2) states that link and match also provides opportunities for Vocational High School students to develop learning creativity in a more realistic educational media. The Vocational High School should be able to utilize this business world as the most effective training media for skills formation and professional attitude of graduate potential. By having the agreement between the school and the business world, teaching and learning activities of learners in Vocational High School will gain a very valuable experience in preparation for entering the job market. This learning process is called multiple system education.

Saraswati (2012, p. 1) conveyed the research result as follows: that there is a role of business world to education of industrial work practice covering the following three sub variables: as provider of practice place for student scored 842 of 10 items, as provider of fund for organizing industrial work practice scored 705 of 10 items, and designs educational programs and imple-mentation program up to evaluation of student learning outcomes in vocational education scored 883 of 10 items. While the business world that has a role in industrial work practice education in SMK Pelayaran Tayu is shipping or nautical business.
Rejokirono (2015) said that field practice provides real experience about the world of work as well trains children to adapt to the environment. While internship provides a direct experience for children in doing the job. Through field practice and internship programs, children are more prepared to enter the world of work. The readiness of the children to enter the world of work can be seen from the competence they have, as well as the number of children who have been accepted to work in DUDI places or open business in groups or open their own business with their family.

According to Purwanto's (2013) agreement, the training curriculum needs to be designed to meet the required competencies in DUDI, in this case it is adjusted to the needs of the level and type of work for technician in PT. Main Trakindo that is well known as Market Driven. The final goal in vocational education is vocational graduates can work in DUDI, therefore students who have taken internship in DUDI are able to know directly their competence so that they can be placed or employed in accordance with their field. One indication of the success of SMK is the absorptivity of graduates in DUDI.

According to Cahyono (2015), regarding the research data about the influence of life skill educational method on vocational skills of mild mentally retarded students, showed that: (1) the application of life skill education method can be applied for mild mentally retarded students to improve the ability of vocational skill in making various flavor of banana chips; (2) in applying life skill education methods, there some consideration should be noted in classroom action research: (a) it is necessary to have a systematic, practical, systematic teaching plan that is simple and easy to implement in the field; (b) the implementation of life skill education method should be carried out seriously and carefully; (3) there are some considerations in applying life skill education method: (a) observer must be very careful in giving treatment when seeing the activities during the students working on vocational activities to make various fla- 
vored banana chips; (b) it is necessary to guide the students' behavior in conducting vocational task of making the chips in the observation. It needs to improve students' behavior.

According to Tukiman \& Jabar (2014, p. 128) the results of his research stated that the leadership of elementary school headmaster of Kanisius Sengkan has built confidence and mutual trust between headmasters, teachers and employees. The trust is built primarily through the trustworthy example of the headmaster's own life. The headmaster always seeks a fit between what is said and what is done.

Some of the study results confirm that learning vocational skills for mild mentally retarded children when it is well planned, organized and well implemented, and conducted an evaluation to determine the result outcomes and for improvement, it will produce qualified learning. Education for mild mentally retarded children should focus on the development of vocational skills proper to the child potential and in accordance with the needs of the world of work, as well as provide working experience through field practice and internship in business places.

\section{Research Method}

The research and development steps of Gall, Gall, \& Borg (2003, p. 775) were developed by researchers into 3 stages: (1) Preliminary research to map the current situation and to find out the need for development, (2) model development stage, and (3) model product testing.

Development Model

Vocational Skills Learning Management Model to prepare mild mentally retarded children to enter the world of work does not stand alone but it is made integrated in classroom learning at SMALB level to improve the quality and relevance of graduates with the needs of the world of work, especially DUDI.

Model development is carried out through three stages: (1) pre-model development stage or preliminary study, (2) mo- del development stage, and (30 validation stage or model testing. The preliminary stage is conducted to determine the current condition of vocational skills learning management and to know the expectations or needs required for development.

Preliminary Study Stage

\section{Literature Study}

The literature study was conducted to collect the supporting materials to make the model draft. Literature study was carried out by studying the books, research journals and articles relevant to the title of this research.

\section{Preliminary Study}

A preliminary study was conducted to find out the current implementation of vocational skills learning management and to find out what is needed for development. Preliminary study included (1) questionnaire distribution, observation and interview to gather the previous information, (2) Focus Group Discussion (FGD) with stakeholders to discuss current skill-learning management conditions and needs for model development; and (3) questionnaires distribution to headmasters, teachers, and parents/families to get additional information about the current condition. Research subjects at this stage consisted of 30 school headmasters, 102 teachers of SLB and 33 parents.

\section{Information Collection Stage}

This stage is conducted through questionnaire distribution to collect information or input for the need of model development. There are 30 headmasters, 102 SLB teachers and 33 parents who take part in this stage.

Development Stage.

There are some activities conducted in the development stage.

Formulating Model Draft.

Draft of vocational skill management model in preparing mild mentally retarded children to enter the world of wok is created 
based on the information and input collected from the literature study, FGD, and questionnaire distribution.

\section{Validating Model Draft by Practitioners and Experts}

Model draft are validated by 14 prospective users (headmaster and teacher) and by 10 expert teams from management, education, special education, vocational skill, and linguistic background. The validation process is initiated by implementing model draft through FGD to obtain some inputs. After conducting FGD, the participants are required to give evaluation seen from the aspect of model systematics, model substance, linguistics, and graphics. The research subjects in this stage consist of 14 practitioners and 10 expert teams.ng.

\section{Revising Model Draft.}

Model revision is carried out based on inputs or guidance from the assigned expert or team. The inputs of the expert team will refine the model draft that is prepared to conduct implementation testing.

\section{Model Testing}

Model testing is carried out through three stages: limited testing with the subject of 6 headmasters of DIY area and 6 teachers of SLB in DIY area that conducting SMALB level. Each respondent is given model draft to implement at school. After they implement the model draft for about one to two months, they are invited to discuss their experiences in implementing the model, their inputs to improve the model, and they complete the questionnaire to evaluate the model. The result of questionnaire scores is analyzed to determine the extent to which the model can be implemented while the inputs are discussed to revise the model.

Model testing is also conducted with small group consisting of 12 headmasters and 9 teachers of SLB in DIY. Small group testing is initiated by implementing model draft in 9 SLB that considered having commitment of appropriate education for mild mentally retarded children orienting the development of vocational skill based on market needs or world of work for mild mentally retarded children. The result of questionnaire scores is analyzed to determine the extent to which the model can be implemented while the inputs in the form of oral explanation will be used as the material to revise the model.

The extended testing is carried out with 33 headmasters and 18 teachers of SLB in DIY area in SMALB level. The extended testing will contribute the evaluation of model effectivity seen from the filled questionnaire while the written or oral inputs during FGD will be used to revise the model. Evaluation points on FGD of the limited testing, small group testing, and extended testing use the same questionnaire that consist of two parts. First part evaluates the model content including 8 items of model systematics, 4 items of model substance, 5 items of linguistics, and 6 items of graphics. Second part evaluates the model implementation consisting of 8 statements or questions, as follows: is the model: (1) needed by the school, (2) important for the school, (3) useful for the school, (4) applicable, (5) simple for school, (6) practicable, (7) easy to apply, and (8) helpful for school. The collected data of the limited testing is ranged at score from 1 to 5 . The higher the score achieved, the model is stated well or meet the need of the development of skill learning management model in preparing mild mentally retarded children in entering the world of work. In contrast, if the score is low, it means the model does not meet the need. Score is analyzed for each item and the whole. The overall average score is then converted into percentage to find out whether it has met the need or not.

Furthermore, to simplify the data analysis, score result is converted into percentage. Then it is converted into category. There are four optional items for the score: A for score 4, B for score 3, C for score 2, and $\mathrm{D}$ for score 1 that converted into the following intervals $0-25 \%$ in very poor category, $26-50 \%$ in poor category, $51-75 \%$ in good category, and $76-100 \%$ in very good category while the five item score has the following options: A for score 5, B for score 4, 
C for score 3, D for score 2 and $\mathrm{E}$ for score 1 with the intervals: $0-20 \%$ in very poor category, $21-40 \%$ in poor category, $41-60 \%$ in fair category, $61-80 \%$ in good category, and $81-100 \%$ in very good category.

Besides the score, there is also data collected from inputs in descriptive form. These inputs will be used as the materials to revise the model that meet the need.

\section{Findings and Discussion}

The whole research and development was conducted in one year. It took from January to June 2016. The fact at the field showed that there's a small number of mild mentally retarded children graduated from SLB that able to work about $10 \%$ while $90 \%$ of the rest is unemployed. Furthermore, the researcher conducted observation and interview to find out the implementation of vocational skill learning management. There was some information gathered through the observation and interview; (1) vocational skill learning is conducted at school but it has not organized field practice or internship program at business place or DUDI, (2) the skill material has not adjusted to the market need, (3) the classification of study group relies on the grade level but it does not consider the homogeneity of skill type chosen by the students, (4) school and teacher have not optimized the role of parents and employer in vocational skill learning, (5) school has not empowered DUDI for field practice and internship program, (6) there is no any powerful commitment yet from the headmaster to prepare mild mentally retarded children in entering the world of work.

Go further, through FGD conducted on 21 July 2016 obtained a lot of inputs about the needs required in the model development. It was formulated model draft through FGD by developing the embryo of model draft combined with FGD participants 'inputs. The formulated model has the following specifications: (1) vocational skill learning is carried out at school and field practice and internship are conducted at business places or DUDI; (2) skill material is adjusted to the market needs; (3) non skill school subjects are delivered through thematic approach with the themes related to the skills chosen by the students and if it is possible to combine vocational skill subjects with non-skill subjects (Indonesian Language, Mathematics, Science, Social, and Civics); (4) classification of study group is based on the homogeneity of skill type chosen by the student; (5) school and teacher optimize the role of parents and employer to take part in vocational skill learningl; (6) school empowers DUDI for field practice and internship program; (7) headmaster should fully committed to prepare mild mentally retarded children in entering the world of work; and (8) education is carried out integrated and continuously from TKLB, SDLB, SMPLB, SMALB, and post school service to accompany mild mentally retarded children in entering the world of work as presented in the following grand design.

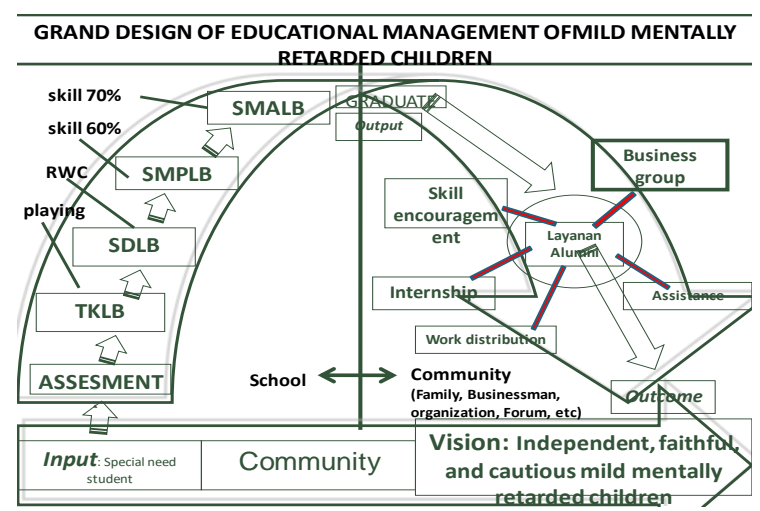

Figure 1. Grand Design of Educational Management of Mild Mentally Retarded Children

Paying attention to Figure 1 educational service for mild mentally retarded children is designed integrally and continuously from Special Kindergarten (TKLB), Special Elementary School (SDLB), Special First Secondary School (SMPLB), Special High School (SMALB), and post school service. This design presenting the description to make mild mentally retarded children able to work should be prepared earlier. Each educational level has potential focus to develop. Figure 1 shows that on TKLB orienting learning with playing design, SDLB learning focusing on reading, writing, and 
counting competence; SMPLB focusing on early vocational competence; SMALB focusing on development of vocational skill competence, continued by transitional service maximally 2 years by school, community organization, and other parties that concern to the mild mentally retarded children future.

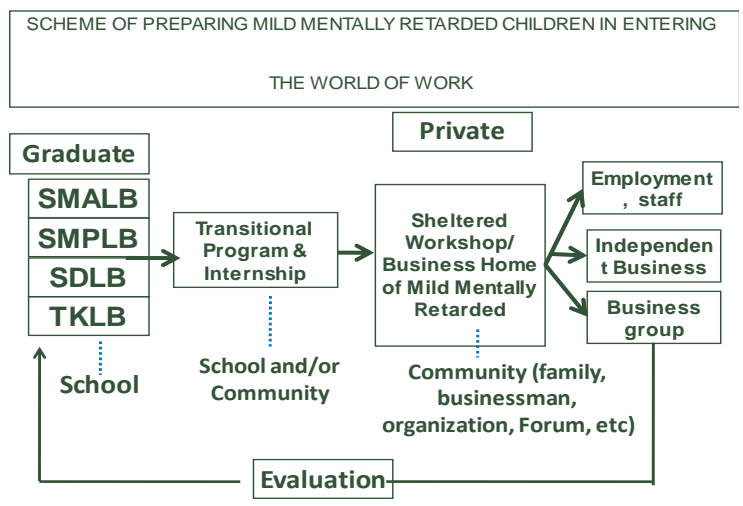

Figure 2. Scheme of Preparing Mild Mentally Retarded Children in Entering the World of Work

Figure 2 emphasizes that education must be fully organized from TKLB, SDLB, SMPLB, SMALB, transition period, distribution to the world of work, and conducted continuous evaluation to give input for future learning improvement. Problems found when the children entering the world of work will give input for improving learning process at school.

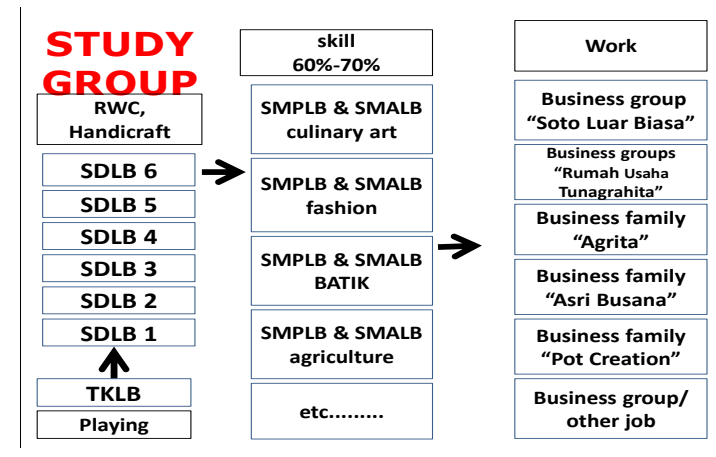

Figure 3. Classification of Study

Group based on Skill Type

The display in Figure 3 shows that the classification of study groups at the SMPLB and SMALB levels is based on the chosen skill type. In one study group can consist of several grade levels, but it has the same choice of vocational skills. Although the children sit in one study group, the material will be tailored to the ability of each child.

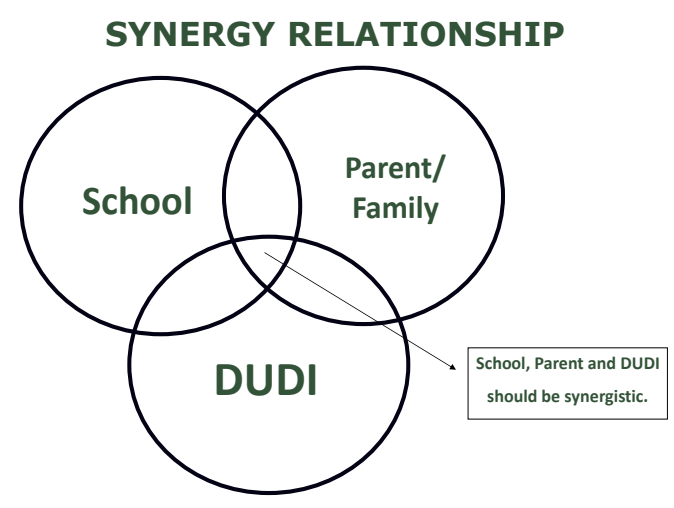

Figure 4. Figure 4 Synergistic Cooperative Relationship

Figure 4 shows that between school, parent, and entrepreneur or DUDI should establish a synergistic, mutually helpful, complementary relationship for the realization of quality learning and can prepare mild mentally retarded children to enter the world of work. Figures 1, 2, 3 and 4 will form the basis of model development that is expected to prepare mild mentally retarded children to enter the world of work. The draft model that has been formulated is further validated by practitioners and experts. The next step after being revised through the validation of practitioners and validation of expert teams, testing and FGD are conducted to determine the level of applicability, and the last stage in this study is the final product revision.

The research findings are as follows:

Implementation of vocational skills learning management.

a. Vocational skills learning materials for mild mentally retarded children are not appropriate to the needs of the world of work/DUDI, and there are too many types of material.

b. Classification of study groups is based on grade level. Children are divided and moved on all types of skills organized by school. 
c. A vocational skill learning approach for mild mentally retarded children set thematically with common themes that unrelated to the skills learned is widely implemented in the classroom.

d. Skill learning methods are lecturing, discussion, and task giving.

e. Vocational skills learning assessment for mild mentally retarded children is carried out through the Learning Outcome Test (semester final test), assessment of school examination.

f. Implementation of field practice and internship is carried through practice in this school. Field practice or internship is not conducted in DUDI.

g. Involvement of the role of parents and employers is limited to membership of the school committee, and limited to attend meeting twice a year.

h. The role of the SLB headmaster is not directly involved in skill learning management. He has no commitment to accompany the child into the world of work. He does not have a follow-up program after the child graduates.

What is required for model development?

a. Learning materials that fit the market needs, vocational skills material followed by one or two kinds of skills, vocational skills based on the potential or needs of the child.

b. Classification of study groups that provide a lot opportunities as many as possible to children to learn skills, and based on the type of selected skill.

c. A learning approach that can encourage children to master certain skills, and an integrative functional thematic learning approach.

d. Learning methods that provide opportunities for children to master the skill competence, the use of drilling methods.

e. Assessment of learning that does not harm the child, assessing the process, results, and portfolio.

f. Organizing field practice and internship directly in the workplace or employer place with adequate time. g. Involvement of the role of parents and employer in selecting skill type for children, school activity and field practice or internship, follow up program after school, and giving input to make the skill teaching meet the need.

h. The world of work that facilitates field practice and internship program.

i. The role of headmaster that fully committed in giving service based on children need, able to bring school community in one vision and mission, able to build network with government institution or private one especially business party.

What kind of appropriate vocational skill learning management model to prepare mild mentally retarded children in entering the world of work?

a. Model with learning material related to the market need, one or two selected vocational skill types, and vocational skill material that go along with the children potentials or their needs. This model is accordance with American Psychiatric Association (2013, p. 36) that vocational skill trained must be adjusted with the difficulty level and the need of children with special need and children carrier development.

b. Model with study group classification which give more chances to students learning skills based on selected skill types.

c. Model with learning approach which supports children in mastering certain skill competence and integrative functional thematic approach.

d. Model with learning method which gives children chance to master skill competence and the use of drilling method.

e. Model with advantageous learning assessment, assessment through process and result, and portfolio.

f. Model with the organization of field practice and internship directly in the workplace or employer place with adequate time.

g. Model with the involvement of the role of parents and employer in selecting 
skill type for children, school activity and field practice or internship, follow up program after school, and giving input to make the skill teaching meet the need of the world of work, and facilitates field practice and internship. This model is in accordance with the research result by Saraswati (2014) stated that business world as field practice, program planning and program implementation.

h. Model with The role of headmaster that fully committed in giving service based on children need, able to bring school community in one vision and mission, able to build network with government institution or private one especially business party. It is in accordance with the research result by Tukiman \& Jabar (2014) that leader or headmaster builds trust especially through trustable headmaster life sample. Headmaster always tries to fit between he says and he does.

Is the model of vocational skill learning management to prepare mild mentally retarded children in entering the world of work effectively applied? Table 1 to 6 is presented to answer question.

The score result of limited testing evaluating of the content of the model is presented in the Table 1.

Table 1. Description of the Respondent' response in Limited Testing Evaluating the Content of the Model

\begin{tabular}{clcc}
\hline No & Aspect & $\begin{array}{c}\text { Average } \\
\text { Score }\end{array}$ & Percentage \\
\hline 1 & Model Systematics & 4.50 & $90.00 \%$ \\
2 & Model Substance & 4.45 & $89.00 \%$ \\
3 & Model Linguistics & 4.53 & $90.60 \%$ \\
4 & Model Graphics & 4.47 & $89.40 \%$ \\
& Total & 17.95 & $359.00 \%$ \\
& Average & 4.49 & $89.75 \%$ \\
\hline
\end{tabular}

The score result of limited testing evaluating of the content of the model describes in the percentage of score 1 there is no one choosing $(0 \%)$, score 2 there is no one choosing $(0 \%)$, score 3 there is no one choosing $(0 \%)$, score 4 reaches $51.45 \%$ dan score 5 reaches $48.55 \%$. This result shows that the model is appropriate and it can be used.

While the score average of each aspect can be described as follows: aspect of model systematics reachesscore average 4.50 (90\%), aspect of model substance reaches score average $4.45(89 \%)$, aspect of linguis-tics reaches score average $4.43(90,6 \%)$, and aspect of graphics reaches score average 4.57 $(89,4 \%)$. The score average from the whole aspects of small group limited testing is 4.49 or 89.75 of the highest score 5 or $89.75 \%$.

The result shows that aspect of model systematics, model substance, model linguistics and model graphics reaches a very high score. It means all aspects are appropriate component to be the material or content of the vocational skill learning management to prepare mild mentally retarded children in entering the world of work.

Furthermore, it is presented the result of model applicability testing. Model applicability is meant to find out how effective the model applied at school. There are 8 items of statement filled by the prospective user to measure the model applicability.

The score result of limited testing evaluating of the model applicability is presented in the Table 2 .

Table 2. Description of the Respondent' response in Limited Testing Evaluating the Model Applicability

\begin{tabular}{llcc}
\hline No & \multicolumn{1}{c}{ Aspects } & $\begin{array}{c}\text { Ave- } \\
\text { rage } \\
\text { Score }\end{array}$ & $\begin{array}{c}\text { Percen- } \\
\text { tage }\end{array}$ \\
\hline 1 & Model is needed by school & 5.00 & $100.00 \%$ \\
2 & Model is essential for school & 4.67 & $93.40 \%$ \\
3 & Model is expected by school & 4.83 & $96.60 \%$ \\
4 & Model is useful for school & 5.00 & $100.00 \%$ \\
5 & Model is helpful for school & 4.67 & $93.40 \%$ \\
6 & Model is simple for school & 4.67 & $93.40 \%$ \\
7 & Model is easily applied & 5.00 & $100.00 \%$ \\
8 & Focus on vocational skill & 4.67 & $93.40 \%$ \\
& development & & \\
& $\quad$ Total & 38.51 & $770.20 \%$ \\
& Average & 4.81 & $96.28 \%$ \\
\hline
\end{tabular}

The score result of limited testing evaluating of the model applicability describes in the percentage of score 1 there is no one choosing $(0 \%)$, score 2 there is no one choos- 
ing $(0 \%)$, score 3 there is no one choosing $(0 \%)$, score 4 reaches $18.75 \%$, and score 5 reaches $81.25 \%$. the percentage result shows that model draft facilitate school in vocational skill learning management and really required. While the score average of the whole 8 items is 4.81 of the highest score 5 (96.28\%).

The result shows that model of vocational skill learning management to prepare mild mentally retarded children in entering the world of work can be applied in a very good category and in general, this model is helpful, facilitating, and well applied.

In the following tables, it is presented the score result of limited testing. The whole aspects consisting systematics, substance, linguistics, and graphics reach very good score with the lowest score 4.45 and the highest one is 4.50 of the highest or maximum score 5 .

\section{Small Group Testing}

Small group testing involves 12 participants of headmaster and teachers from 9 SLB in Special region of Yogyakarta. Testing process is initiated by applying the model and ended by distributing questionnaire with four aspects consisting of 23 items to evaluate the content of model and 8 items to evaluate the model applicability. The result of small group testing to evaluate the content of the model is presented in Table 3.

Table 3. Description of the Prospective User in Limited Testing Evaluating the Content of the Model

\begin{tabular}{clcc}
\hline No & \multicolumn{1}{c}{ Aspect } & $\begin{array}{c}\text { Average } \\
\text { Score }\end{array}$ & Percentage \\
\hline 1 & Model Systematics & 4.45 & $89 \%$ \\
2 & Model Substance & 4.39 & $87.8 \%$ \\
3 & Model Linguistics & 4,32 & $86.4 \%$ \\
4 & Model Graphics & 4.40 & $88 \%$ \\
& Total & 17.56 & $351.2 \%$ \\
& Average & 4.39 & $87.8 \%$ \\
\hline
\end{tabular}

The score result of limited testing describes in the percentage of questionnaire 1 there is no one choosing $(0 \%)$, score 2 there is no one choosing $(0 \%)$, score 3 there is no one choosing $(0 \%)$, score 4 reaches $41.30 \%$ and score 5 reaches $58.70 \%$. this result shows that the model is appropriate and it can be applied.

While the score average of each aspect in questionnaire 1 is described as follow: aspect of model systematics reaches 4.45 , aspect of model substance reaches 4.39 , aspect of linguistics reaches 4.32, and aspect of graphics reaches 4.40 . the average of whole aspect score is 4.39 , the result shows that the percentage $87.8 \%$ in very good category.

Table 4 presents the result of small group testing in evaluating model applicability.

Table 4. Description of the Prospective User in Limited Testing Evaluating the Model Applicability

\begin{tabular}{clcc}
\hline No & Aspect & $\begin{array}{l}\text { Ave- } \\
\text { rage } \\
\text { Score }\end{array}$ & $\begin{array}{l}\text { Percen- } \\
\text { tage }\end{array}$ \\
\hline 1 & Model is needed by school & 4.75 & $95 \%$ \\
2 & Model is essential for school & 4.92 & $98.4 \%$ \\
3 & Model is expected by school & 4.58 & $91.6 \%$ \\
4 & Model is useful for school & 4.67 & $93.4 \%$ \\
5 & Model is helpful for school & 4.75 & $95 \%$ \\
6 & Model is simple for school & 4.58 & $91.6 \%$ \\
7 & Model is easily applied & 4.75 & $95 \%$ \\
8 & Focus on vocational skill & 4.50 & $90 \%$ \\
& development & 37.5 & $750 \%$ \\
\multicolumn{2}{c}{ Total } & 4.69 & $93.75 \%$ \\
\hline
\end{tabular}

The score result of limited testing evaluating of the model applicability describes in the percentage of score 1 there is no one choosing $(0 \%)$, score 2 there is no one choosing $(0 \%)$, score 3 there is no one choosing $(0 \%)$, score 4 reaches $31.25 \%$, and score 5 reaches $68.75 \%$. The average score on questionnaire 2 evaluating model applicability is 4.69. the result shows that percentage $93.8 \%$ in very good category. The result shows that model of vocational skill learning management to prepare mild mentally retarded children in entering the world of work can be very well applied.

\section{Extended Testing}

The extended testing involves 30 participants consisting of headmaster and teacher of 18 selected SLBs in DIY. The selected SLBs are assigned based on the track 
record that those schools have paid attention toward vocational skill learning, and fully committed in preparing mild mentally retarded children in entering the world of work. The third testing is conducted by organizing FGD initially about the implemented model and questionnaire distribution to find out whether the model can be applied. Testing process of the extended testing is initiated by applying model, FGD and ended by questionnaire distribution. Testing is initiated by applying model and ended by completing questionnaire of 4 aspects covering 23 items to evaluate the content of the model, and 8 items of model applicability. The score result of extended testing in evaluating the content of the model can be seen in the Table 5.

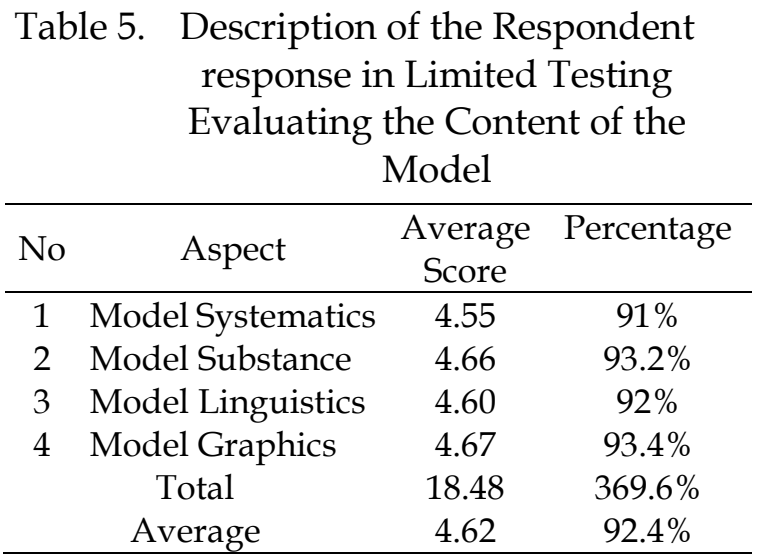

The extended testing involves 33 respondents of headmaster and teacher from 18 SLBs which conducting SMALB level for mild mentally retarded children, and already applied model draft of vocational skill learning management to prepare mild mentally retarded children in entering the world of work.

The score result of limited testing evaluating of the content of the model describes in the percentage of score 1 there is no one choosing $(0 \%)$, score 2 there is no one choosing $(0 \%)$, score 3 there is no one choosing $(0 \%)$, score 4 reaches $46.09 \%$ and score 5 reaches $52.61 \%$. the result shows that model is appropriate and it can be applied. The score average of each aspect on questionnaire 1 is as follows: aspect of model systematics reaches 4.55; aspect of model substance reaches 4.66; aspect of linguistics reaches 4.60; and aspect of graphics reaches 4.67. the average of the whole aspects is 4.62 ; in percentage of $92.4 \%$ under very good category. Both written and spoken inputs delivered on FGD will be used in revising the model that more appropriate to children need and world of work chance.

Moreover, Table 6 presents the score result of the extended testing in evaluating model applicability.

Table 6. Description of the Respondents' Response in Extended Testing Evaluating the Model Applicability

\begin{tabular}{clcc}
\hline No & \multicolumn{1}{c}{ Aspect } & $\begin{array}{c}\text { Ave- } \\
\text { rage } \\
\text { Score }\end{array}$ & $\begin{array}{c}\text { Percen- } \\
\text { tage }\end{array}$ \\
\hline 1 & Model is needed by school & 4.80 & $96 \%$ \\
2 & Model is essential for school & 4.77 & $95.4 \%$ \\
3 & Model is expected by school & 4.70 & $94 \%$ \\
4 & Model is useful for school & 4.43 & $88.6 \%$ \\
5 & Model is helpful for school & 4.60 & $92 \%$ \\
6 & Model is simple for school & 4.37 & $87.4 \%$ \\
7 & Model is easily applied & 4.47 & $89.4 \%$ \\
8 & Focus on vocational skill & 4.73 & $94.6 \%$ \\
& development & & \\
& Total & 36.87 & $737.4 \%$ \\
& Average & 4.61 & $92.18 \%$ \\
\hline
\end{tabular}

The score result of limited testing evaluating of the model applicability describes in the percentage of score 1 there is no one choosing $(0 \%)$, score 2 there is no one choosing $(0 \%)$, score 3 there is no one choosing $(0 \%)$, score 4 reaches $39.17 \%$, and score 5 reaches $60.83 \%$. while the average score is 4.61 , in percentage shows $92.18 \%$ under very good category. The percentage result shows that model draft facilitates school and really required. Those tables answer the question 4 as follows:

a. The implementation of systematics aspect shows that it can be well applied. It can be seen from the limited testing score that reaches $4.50(90 \%)$; score of small group testing reaches 4.45 (89\%); and the score of extended testing reaches 4.55 (91\%).

b. The implementation of substance aspect shows that it can be well applied. It can be seen from the score percentage of 
limited testing reaches $4.45(89 \%)$; small group testing reaches 4.39 (87.8\%); and the extended testing reaches score of 4.66 $(93 \%)$.

c. The implementation of linguistics aspect shows that it can be well applied. It can be seen from the score percentage of limited testing reaches $4.43(90.6 \%)$; small group testing reaches $4.32(86.4 \%)$; and the extended testing reaches score of 4.60 $(92 \%)$.

d. The implementation of graphics aspect shows that it can be well applied. It can be seen from the score percentage of limited testing reaches 4.57 (89.4\%); small group testing reaches $4.40(88 \%)$; and extended testing reaches score of 4.67 $(93.4 \%)$.

e. Model is really needed by school. It can be seen from the score result of limited testing reaches $5.00(100 \%)$; small group testing reaches 4.75 (95\%); and extended testing reaches score of 4.80 (96\%).

f. Model is essential for school. It can be seen from the score result of limited testing reaches $4.67(93.4 \%)$; small group testing reaches $4.92(98.4 \%)$; and the extended testing reaches score of 4.77 (95.4\%).

g. Model is really expected by the school. It can be seen from the score result of limited testing reaches 4.83 (96.6\%); small group testing 4.58 (91.6\%); and the extended testing reaches score of $4.70(94 \%)$.

h. Model is very useful for school. It can be seen from the score result of limited testing reaches $5.00(100 \%)$; small group testing reaches 4.67 (93.4\%); and the extended testing reaches score of 4.43 (88.6\%).

i. Model is very helpful for school. It can be seen from the score result of limited testing reaches 4.67 (93.4\%); small group testing 4.75 (95\%); and the extended testing reaches score of $4.60(92 \%)$.

j. Model is simple for school. It can be seen from the score result of limited testing reaches 4.67 (93.4\%); small group testing reaches $4.58(91.6 \%)$; and the extended testing 4.37 (87.4\%).

k. Model is practicable used. It can be seen from the score result of limited testing reaches $5.00(100 \%)$; small group testing
4.75 (95\%); and the extended testing reaches score of $4.47(89.4 \%)$.

1. Model can be well applied. It can be seen from the score result of limited testing reaches 4.67 (93.4\%); small group testing reaches $4.50(90 \%)$; and the extended testing reaches $4.73(94.6 \%)$.

The impact of changing the vocational skill learning management can be seen from several indicators below:

1) Empowerment of active communication among teacher, parent, and employer in educating and training children to be skillful and adjusted to the need of market and children.

2) Empowerment of active and harmonic communication between mild mentally retarded children and business party so it can improve children' confidence, and employer's understanding to the children.

3) Forming the fully committed community in giving mild mentally retarded children space and chance to work in each activity involving them as part of the activity.

4) Proving some of mild mentally retarded children that can work as follows:

a) Sahid Gurid works for grocery store on Jl. Imogiri Timur Yogyakarta, responsible for distributing to the distributors.

b) Febriansyah Andrianto works for company of Sabun Nuansa Wangi Alam in Gunungpati Semarang, responsible for production and packing process.

c) Nanang \& Fajar Nugroho work for Bixa Batik (natural colored Batik), responsible for slamming and other process.

d) Four children (Sahid, Eko, Darmaji, \& Faldian) had got internship in Sidomuncul Pupuk Nusantara Semarang, for two months and stated pass in satisfied category can adapt well, work well, and given chance to be permanent employer.

e) Mahendra Yusron, Sifa, \& Nurul, work for DJ. Collection Bangunta- 
pan Bantul Yogyakarta, fashion and embroidery.

f) Hari Prasetyo works for Batik Gaul in Malangan Banguntapan Bantul, fashion and embroidery factory.

g) Purbo Tri Laksono opens motor, car, and carpet wash at his home gaining fully support from his parents.

h) Establishment of Educational and Empowerment Foundation of Indonesian Special Mild Mentally Retarded Children (YAPPASTI), that becomes pioneer and educational consultant for mild mentally retarded children by implementing model of vocational skill learning management to prepare mild mentally retarded children in entering the world of work and supports the community establishment that gives space and chance to children work. The YAPPASTI guided children consist of 30 children that being prepared to work.

\section{Conclusion}

The research product is the model of vocational skill learning management to prepare mild mentally retarded children in entering the world of work. The model is ensured as one of the solutions to overcome problem faced by the alumni of SLB who have not got empowerment optimally. Model of vocational skill learning management to prepare mild mentally retarded children in entering the world of work is a kind of comprehensive, integrated, continuous, and functional learning. In this model, learning involves the active role of family, business party, and community and oriented to children ability and their need to master certain vocational skill as the preparation entering the world of work.

Model of vocational skill learning management has been arranged through a long process from need analysis, writing model draft, model validation, model revision, field testing, and revision of final model. Therefore, model has been adjusted to the need of prospective user as involving teach- ers, headmasters, parents, and stakeholders of the related education.

The model has the following specification: (1) vocational skill material has been adjusted to the need of DUDI or market so the students' vocational skill competence appropriate to the need of DUDI or market; (2) study group classification is based on the similarities of the skill types not on the class grade; (3) the use of thematic learning process approach with the relevant themes of skill; (4) the use of skill training method (drill method); (5) the implementation of portfolio learning evaluation; (6) the organization of field practice (PKL) and internship at DUDI; (7) the participation of parents and employer role in vocational skill learning; and (8) the existence of headmaster role who can implement management function well.

The implementation of the model of vocational skill learning management to prepare mild mentally retarded children in entering the world of work optimally has several implications as follows: (1) Headmaster should have vision and mission and strong desire to bring skillful mild mentally retarded children and ready to enter the world of work by establishing a big cooperation between parents and employer; (2) Schools have the courage to implement learning by prioritizing the development of vocational skills and increase learning directly in places of employers; (3) Schools use a modified curriculum by providing adequate vocational skills content, tailored to the child's potential and potential environments including market potential; (4) the headmaster is dare to step out of the monotonous learning to take con-crete steps to provide the children' experience of conducting business training in business premises, and tries to empower or distribute to work.

\section{References}

Abtahi, M. S., Naraghi, M. S., \& Shariatmadari, A. (2010). The role of job empowerment in the hight school vocational curriculum for the trainable mentally retarded male student in Iran. 
Middle-East Journal of Scientific Research, 6(5), 517-531.

American Psychiatric Association. (2013). Diagnostic and statistical manual of mental disorders (5th ed.). American Psychiatric Association.

https:/ / doi.org/10.1176/appi.books.97 80890425596

Anwaruhamka. (2010). Peran dunia usaha dan dunia industri (DUDI) dalam dunia pendidikan. Retrieved January 18, 2015, from

http://anwaruhamka20.wordpress.com

Cahyono, B. D. (2015). Penerapan metode life skill education untuk meningkatkankemampuan vokasional pada anak tunagrahita ringan kelas $X$ sekolah luar biasa. Jurnal Pendidikan Khusus, 7(3). Retrieved from http://jurnalmahasiswa.unesa.ac.id/in dex.php/jurnal-pendidikankhusus/article/view/12625

Gall, M. D., Gall, J. P., \& Borg, W. R. (2003). Educational research: an introduction (7th ed.). Boston: Allyn \& Bacon.

Levinson, E. M., \& Palmer, E. J. (2005). Preparing students with disabilities for school-to-work transition and postschool life. Retrieved January 10, 2015, from https:// my.vanderbilt.edu/specialeduc ationinduction/files/2011/09/Transitio n-Planning1.pdf

Mumpuniarti. (2006). Manajemen pembinaan vokasional bagi tunagrahita di sekolah khusus tunagrahita. Jurnal Pendidikan Khusus (JPK), 2(2).

Nanda, D. S., Silvia, R. T., \& Kasiyati. (2014). Pelaksanaan program transisi ke pascasekolah bagi tunagrahita ringan di SLBN Center Payakumbuh. Jurnal Ilmiah Pendidikan Khusus E-JUPEKhu, 3(3).

Purwanto, D. (2013). Manajemen kerja sama antara sekolah menengah kejuruan dengan industri: Studi kasus di SMK N 1 program keahlian alat berat Singosari Malang. Retrieved from http://www.vedcmalang.com/pppptk boemlg/edukasi/488

Rejokirono. (2015). Menyiapkan anak tunagrahita memasuki dunia kerja melalui praktik kerja lapangan (PKL) dan magang kerja. In International Seminar on Special Education (ISSE). Surabaya: Universitas Negeri Surabaya.

Saraswati, I. (2012). Peran dunia usaha terhadap pendidikan praktik kerja industri. Jurnal Ilmiah IKIP Veteran Semarang Prodi Pendidikan Teknik Mesin Otomotif, GARDAN, 2(2).

Shahid, M. N., Naheed, Z., \& Javed, U. T. and W. (2012). Evaluation of vocational rehabilitation of special people. Asian Journal of Business and Management Scient, 2(7), 14-20. Retrieved from http://www.ajbms.org/journal_abstrac t.php?c_id=189

Steyn, G. M., \& Vlachos, C. J. (2011). Developing a vocational training and transition planning programme for intellectually disabled students in South Africa: a case study. Journal of Social Sciences, 27(1), 25-37. https:// doi.org/10.1080/09718923.2011. 11892903

Supartini, E., Suharmini, T., \& Purwandari. (2010). Pengembangan model pendidikan kecakapan hidup bagi anak tunagrahita di Sekolah Luar Biasa Daerah Istimewa Yogyakarta. Jurnal Asesmen Dan Intervensi Anak Berkebutuhan Khusus, 9(1).

Syamsi, I. (2010). Membuka peluang berwirausaha untuk pemberdayaan anak berkebutuhan khusus. Jurnal Pendidikan Dan Kebudayaan Balitbang Kemdiknas, 16(Special Edition).

Tukiman, \& Jabar, C. S. A. (2014). Implementasi kepemimpinan transformasional kepala sekolah dalam meningkatkan mutu sekolah di SD Kanisius Sengkan Kabupaten Sleman. Jurnal Akuntabilitas Manajemen Pendidikan, 2(1). Retrieved from https://journal.uny.ac.id/index.php/ja $\mathrm{mp} /$ article/view/2414 